\title{
Clinical characteristics and incidence of bacterial and viral pathogens in patients hospitalized with community acquired pneumonia in childhood in Konya between October 2008 and February 2010
}

\section{Konya'da Ekim 2008 - Şubat 2010 tarihleri arasındaki çocukluk çağında toplum kökenli pnömoni tanısı ile hastaneye yatırılan hastalarda bakteriyel ve viral etkenlerin insidansı ve klinik özellikleri}

\author{
Sadiye SERT ${ }^{1}, \quad$ Melike EMIROĞLU ${ }^{2}, \quad$ Uğur ARSLAN ${ }^{3}, \quad$ Osman KOÇ ${ }^{4}, \quad$ Rahmi ÖRS
}

\begin{abstract}
Objective: It was aimed to investigate clinical characteristics and incidence of bacterial and viral pathogens in patients who were hospitalized with the clinical diagnosis of community acquired pneumonia (CAP).

Method: In this study 91 patients at the ages between one month and six years who required hospitalization and were admitted to pediatrics clinics and pediatric emergency services of the Selçuk University Meram Medical Faculty, and also who did not use antibiotics for 48 hours before hospital admission and had the clinical diagnosis of CAP were investigated from October 2008 to February 2010. Demographic and clinic characteristics of the patients were recorded. Blood samples for complete blood count, erytrocyte sedimentation rate, C-reactive protein, procalcitonin, blood culture and nasopharyngeal aspirate samples for detection of the viral etiologies by real time polymerase chain reaction (RT-PCR) were taken at the time of hospital admission. Initial posteroanterior (PA) chest X-rays of all patients were checked.
\end{abstract}

Results: The agents of pneumonia were detected in $24.2 \%(22 / 91)$ but not in $75.8 \%(69 / 91)$ of our patients. Of 91 patients, $11(12.1 \%)$ were positive for viral infections, 9 (9.9\%) were positive for only bacterial infections, 3 (3.3\%) had viral coenfection, 2 (2.2\%) were positive for both viral and bacterial infections. Out of 11 viral positive patients, $7,2,1,2$, and 1 patients

\section{ÖZET}

Amaç: Bu çalışmada; toplum kökenli pnömoni tanısı (TKP) ile hastaneye yatırılan hastalarda bakteriyel ve viral etkenlerin insidansı ve klinik özellikleri araştırılması amaçlanmıştır.

Yöntem: 1 Ekim 2008-28 Şubat 2010 tarihleri arasında Selçuk Üniversitesi Meram Tıp Fakültesi Çocuk Poliklinikleri ve Çocuk Acil Servisine bașvuran ve yatırılarak tedavi edilmesi gereken, bașvurudan 48 saat öncesine kadar antibiyotik kullanmayan, klinik olarak TKP tanısı olan, yaşları 1 ay ile 16 yaş arasındaki toplam 91 hasta çalıșma kapsamına alındı. Bu hastaların demografik ve klinik özellikleri kaydedildi. Hastane bașvurusu esnasında tam kan sayımı, eritrosit sedimantasyon hızı, C-reaktif protein, prokalsitonin, kan kültürü için kan numuneleri ve viral etiyolojiyi gerçek zamanlı polimeraz zincir reaksiyonu (RT-PCR) ile saptamak amaciyla nazofaringeal aspirat numuneleri alındı. Tüm hastaların PA akciğer radyografileri kontrol edildi.

Bulgular: Hastaları \%24,2 (22/91)'sinde pnömoni etkeni saptanırken, \%75,8 (69/91)'inde herhangi bir pnömoni etkeni saptanamadı. 91 hastanın 11 (\%12,1)'inde viral enfeksiyon, dokuzunda $(\% 9,9)$ sadece bakteriyel enfeksiyon, üçünde (\%3.3) viral koenfeksiyon, ikisinde $(\% 2,2)$ hem virus hem de bakteri vard. Virus tespit edilen 11 hastanın yedisinde Parainfluenza (PIV) 2, ikisinde PIV 3, birinde adenovirus, ikisinde hem PIV3 hem

${ }^{1}$ Department of Pediatrics, Beyhekim State Hospital, KONYA, TURKEY

${ }^{2}$ Department of Pediatric Infectious Diseases, Faculty of Medicine, Selcuk University, KONYA, TURKEY

${ }^{3}$ Department of Microbiology, Faculty of Medicine, Selcuk University, KONYA, TURKEY

${ }^{4}$ Department of Radiology, Faculty of Medicine, Necmettin Erbakan University, KONYA, TURKEY

${ }^{5}$ Department of Pediatrics, Faculty of Medicine, Necmettin Erbakan University, KONYA, TURKEY

İletişim/Corresponding Author: Sadiye SERT

Department of Pediatrics, Beyhekim State Hospital, KONYA, TURKEY

Tel : +903322243000

E-posta/E-mail : sadiyesert@yahoo.com.tr

Geliş Tarihi / Received : 06.08.2015

Kabul Tarihi / Accepted : 01.01 .2016

DOI ID : 10.5505/TurkHijyen.2016.86547

Sert S, Emiroğlu M, Arslan U, Koç O, Örs R. Clinical characteristics and incidence of bacterial and viral pathogens in patients hospitalized with community acquired pneumonia in childhood in Konya between October 2008 and February 2010. Turk Hij Den Biyol Derg, 2016; 73(2): 101-10. 
were detected to have parainfluenza virus (PIV) 2, PIV 3, adenovirus, both PIV 3 and adenovirus, both PIV 2 and PIV 3, respectively. RSV, PIV 1 and human metapneumovirus (hMPV) were not detected in any of cases. Out of 11 bacteria positive patients, 5, 2, 1, 1, 1, and 1 patients were detected to have Staphylococcus epidermidis, S. saprophyticus, S. hominis, S. capitis, S. sobrinus and S. mitis. Also mixed viral-bacterial agent presence were detected in 2 (2.2\%) of our patients. Out of ninety one pneumonia patients those having their diagnosis clinically, 59 (64.7\%) had radiological signs.

Conclusion: Our study demonstrated the etiological influence of viral agents in CAP. Parainfluenza virus 2 was the most common viral agent among detected viruses in all age groups. Improving the etiological diagnosis of viral infections may avoid unnecessary the use of antibiotic. Further comprehensive and randomized controlled studies are needed to confirm our results.

Key Words: Childhood, etiology, community acquired pneumonia, real time-PCR adenovirus, birinde hem PIV2 hem de PIV3 tespit edildi. Hastaların hiçbirinde RSV, PIV1, hMPV saptanmadı. Bakteri tespit edilen 11 hastanın beșinde Stafilokokus epidermidis, ikisinde S. saprophyticus, birinde $S$. shominis, birinde $S$. capitis, birinde $S$. sobrinus ve birinde $S$. mitis tespit edildi. Hastaların ikisinde de viral-bakteriyel karma etken olduğu saptandı. Klinik olarak pnömoni tanısı alan 91 hastanın 59 (\%64,7)'unda radyolojik olarak pnömoni varlığı belirlendi.

Sonuç: Çalıșmamız TKP'de viral etkenlerin etiyolojik etkisini gösterdi. Parainfluenza virus 2 tüm yaş gruplarında en sık tespit edilen viral etkendi. Viral enfeksiyonların etiyolojik tanılarının iyileștirilmesi ile gereksiz antibiyotik kullanımından kaçınılabilir. Sonuçlarımızı doğrulamak için daha kapsamlı ve randomize kontrollü çalıșmalara gereksinim vardır.

Anahtar Kelimeler: Çocukluk çağı, etiyoloji, toplum kökenli pnömoni, gerçek zamanlı PZR

\section{INTRODUCTION}

Childhood community-acquired pneumonia (CAP) remains a leading cause of morbidity and mortality worldwide. The aetiological agents, patient age, clinical manifestations and seasonal occurrence of childhood CAP vary between countries. Rational antibiotic treatment requires knowledge of the most likely pathogens in each geographical region (1). Recent estimates from the World Health Organization (WHO) suggest that pneumonia is responsible for $20 \%$ of deaths in $<5$ years of age group, leading to 3 million deaths per year. Of these deaths, two thirds occur during infancy and more than $90 \%$ occur in the developing countries (2). There have been relatively few comprehensive studies of the viral and bacterial etiology of CAP in children. Identifying the cause of CAP in children is difficult for several reasons. The procedures used to confirm the pathogen, such as bronchoalveolar lavage and lung puncture for bacterial culture, are too invasive. The positive rate for blood cultures in pneumonia is only 0 to $5 \%$ in cases in developed countries (3-6).

Viral pathogens are gradually recognized as playing a major role in the etiology of lower respiratory tract infections (LRTIs), and are considered the predominant pathogens in CAP in preschool children (7). As these respiratory viral pathogens cause very similar clinical symptoms, differential diagnosis of the pathogens is required in appropriate sample. Monospecific PCR assays require separate amplification of each target and are therefore expensive and resource intensive. For clinical diagnosis, multiplex PCR has a significant advantage, as it permits simultaneous amplification of several viruses in a single reaction mixture, facilitating cost-effective diagnosis (8). Real-time PCR method was found to be more sensitive than cell culture on a range of different respiratory samples. 
The specificity of the real-time PCR was reported to be as high as $93 \%$ and the sensitivity as $100 \%$ (9). Thus, in our study we used multiplex real-time PCR method for diagnosis and differentiation of different viral agents.

Comprehensive information on the etiology of CAP is required for the formulation of treatment recommendations and the introduction of preventive measures. Evaluation of mixed infections and the relative importance of each potential pathogen may also contribute to improved understanding of the etiopathogenesis of CAP (10).

We aimed to investigate clinical characteristics and incidence of bacterial and viral pathogens in children aged one month to 16 years who were hospitalized for CAP.

\section{MATERIAL AND METHODS}

\section{Study design}

The study was a 17-months study. We evaluated to investigate clinical characteristics and incidence of bacterial and viral pathogens among children who were diagnosed and hospitalized for CAP. Patients aged one month to 16 years old diagnosed as CAP by inclusion criteria were recruited into the study. The study was approved by the local ethics committee, and written informed consent was obtained from parents of all patients. A patient was enrolled in the study if she/he met the following criteria (11). Fever with body temperature $>37.8^{\circ} \mathrm{C}$, respiratory rate more than average per age by WHO criteria, abnormal chest $\mathrm{x}$-ray together with signs of respiratory distress. Children were excluded if they were currently on antibiotic therapy or were admitted to hospital for more than 48 hours. Upon enrolment, demographic characteristics and baseline clinical data were recorded. Pulmonary auscultation findings of each patient were recorded with detailed physical examination.

\section{Study population}

From October 2008 to February 2010, 91 children aged one month to 16 years ( 44 girls and 47 boys, median age: 11 months) who were diagnosed as CAP and were hospitalized at department of pediatrics, Selcuk University Hospital, Konya, Turkey were included in the study.

\section{Radiology}

A senior radiologist, unaware of clinical and laboratory findings, reviewed all chest radiographs. Chest $\mathrm{x}$-rays were interpreted and recorded radiological findings such as normal chest radiography, consolidation, interstitial infiltration, peribronchitis, hiler/mediastinal lymphadenopathy, atelectasis, air broncogram, pleural effusion, and hyperinflation by the radiologist.

\section{Microbiology}

A nasopharyngeal sample was aspirated through a nostril and kept under $-80^{\circ} \mathrm{C}$ until virologic tests ( $\mathrm{n}$ $=91$ ) were done. Existence and genotyping of viruses (PIV type 1, 2 and 3, respiratory syncytial virus (RSV), adenovirus and human metapneumovirus) causing viral CAP were investigated with RT-PCR. Viral DNA isolation of a nasopharyngeal sample was made by using High Pure PCR Template Preparation (Cat.No. 11796828 001, Roche Diagnostic, Germany). RT-PCR device (LightCycler ${ }^{\circledR}$, Roche Diagnostic, Germany) was used for detection of pathogens. The virologic studies were carried out at the Department of Microbiology, Selcuk University Hospital, Konya.

Serum procalcitonin (PCT) levels were measured with BRAHMS PCT reactive (BRAHMS- Diagnostica, Berlin/ Germany). Assays were performed with Lumat LB 9501 immünoassay device (Roche Diagnostics GmbH, Mannheim, Germany) by using immünoluminometric method.

Serum C-reactive protein (CRP) levels were measured using Nephelometer 100 Device (Dade Behring Marburg, Germany).

Erythrocyte sedimentation rate (ESR) measurements were performed by using fully automated ESR assay device (Diesse Ves Cube 200, Diesse Diagnostica Senese SpA, Italy). 
Complete blood count (CBC) assays were performed with fully automated CBC device (CellDyne 3700, Abbott Diagnostics Division, Abbott Laboratories, Abbott Park IL, USA).

Blood cultures were obtained via BD Bactec Peds Plus/F vials before initiation of parenteral antibiotic therapy among all patients and incubated in automated blood culture system (Bactec 9240 BD, Becton Dickinson and Company, Sparks MD, USA). Isolated strains were also identified by using automated bacteria identification system (VITEK 2, Biomerieux, Marcy l'Etoile, France).

\section{Statistical analysis}

Data were reported as mean \pm SD, minimummaximum (range) or percent. After testing for normality with a one sample Kolmogorov-Smirnov test, differences in the means of variables were evaluated using both parametric (Student's t-test) and nonparametric tests (Mann-Whitney U-test) depending on the distribution of the variables. Categorical data were analysed with the chi-square test or Fischer's exact test. Results were considered significant if $p<0.05$. Statistical analyses were performed with the Statistical Package for Social Science program (SPSS version 15.0 for Windows; Chicago, IL).

\section{RESULTS}

The demographic and clinical features of the patients with CAP were shown in Table 1. The study included 47 (51.6\%) boys and 44 (48.4\%) girls. The median age of the patients was 11 months, ranging from 1 to 192 months. Nasal congestion and rhonchi were significantly frequent than in patients with viral infection when compared to those with bacterial pneumonia $(p=0.049, p=0.028)$. The agents of pneumonia were detected in $24.2 \%$ (22/91) with nasopharyngeal aspirate and blood culture but not in $75.8 \%(69 / 91)$ of our patients. Of 91 patients, 11 (12.1\%) were positive for viral infections, 9 (9.9\%) were positive for only bacterial infections, 3 (3.3\%) had viral coinfection, 2 (2.2\%) were positive for both viral and bacterial infections. Out of 11 viral positive patients, 7, 2, 1, 2, and 1 patients were detected to have parainfluenza virus (PIV) 2, PIV 3, adenovirus, both PIV 3 and adenovirus, both PIV 2 and PIV 3, respectively. RSV, PIV 1 and human metapneumovirus virus were not detected in any of cases. Out of 11 bacteria positive patients, 5, 2, 1, 1, 1, and 1 patients were detected to have Staphylococcus epidermidis, Staphylococcus saprophyticus, Staphylococcus hominis, Staphylococcus capitis, Streptococcus sobrinus and Streptococcus mitis. Also mixed viralbacterial agent presence were detected in 2 (2.2\%) of our patients. Table 2 shows viral and bacterial agents causing CAP in hospitalized children.

The mean body temperature on admission was $37.9 \pm 1.05^{\circ} \mathrm{C}$. Considering the pulmonary auscultation findings of the patients, crackles, rhonchi and wheezing were found in 85 (93.4\%), 54(59.3\%) and 38 (41.8\%) children, respectively. The median leukocyte count, CRP, PCT and ESR values were $9000 / \mathrm{mm}^{3}, 10.7$ $\mathrm{mg} / \mathrm{L}, 0.13 \mathrm{ng} / \mathrm{mL}, 13 \mathrm{~mm} / \mathrm{h}$, respectively.

The distributions of etiologic agents of communityacquired pneumonia according to different age groups were shown in Table 3. PIV-2 had the highest rate among detected viruses in all age groups. Adenovirus was detected only in one patient in 2-11 months of age group. Parainfluenza 3 were found in $<2$ and 2-11 months of age group. PIV-2 was the most common viral agent among $<2$ and 2-11 months of age group. Positive blood culture was detected the higher in $<2$ months of age group than those in other groups.

There was no statistically significant difference between viral and bacterial pneumonia groups with regard to ESR values $(p=0.669)$. Also, there was no statistically significant difference between viral and bacterial pneumonia groups with regard to $P C T$ values $(p=0.993)$. The radiological findings of patients with CAP were shown in Table 4. Chest $x$ ray showed notable alveolar 
Table 1. The demographic and clinical features of the patients with CAP

\begin{tabular}{|c|c|}
\hline \multicolumn{2}{|l|}{ Demographic features } \\
\hline Gender & \\
\hline Boy & $47(51.6) \dagger$ \\
\hline Girl & $44(48.4)$ \\
\hline \multicolumn{2}{|l|}{ Age (Month) } \\
\hline Median (Range) & $11(1-192)$ \\
\hline \multicolumn{2}{|l|}{ Residential area } \\
\hline Urban & 70 (76.9) \\
\hline Rural & $21(23.1)$ \\
\hline Underlying diseases & $14(15.4)$ \\
\hline \multicolumn{2}{|l|}{ Vaccination } \\
\hline Appropriate according to age & $91(100)$ \\
\hline At least one time hospitalising for lower respiratory tract infection & $18(19.8)$ \\
\hline Antibiotic therapy in the last month & $51(56)$ \\
\hline \multicolumn{2}{|l|}{ Age of mother (Year) } \\
\hline Mean & $28.4 \pm 5.6$ \\
\hline Median (Range) & $28(18-47)$ \\
\hline \multicolumn{2}{|l|}{ Age of father (Year) } \\
\hline Mean & $31.5 \pm 5.6$ \\
\hline Median (Range) & $31(22-49)$ \\
\hline Family history of atopy & $11(12.1)$ \\
\hline Upper respiratory tract infection in family during the last month & $61(67)$ \\
\hline Environment related to smoking & $39(42.9)$ \\
\hline \multicolumn{2}{|l|}{ Clinical presentation } \\
\hline Fever & $90(98.9)$ \\
\hline Cough & 90 (98.9) \\
\hline Wheezing & $71(78)$ \\
\hline İrritability & $65(71.4)$ \\
\hline Poor feeding & $61(67)$ \\
\hline Dyspnea & $58(63.7)$ \\
\hline Vomiting & $44(48.4)$ \\
\hline Cyanosis & $34(37.4)$ \\
\hline Rhinorrhoea & $30(33)$ \\
\hline Nasal congestion & $24(26.4)$ \\
\hline Productive cough & $23(25.3)$ \\
\hline Headache & $13(14.3)$ \\
\hline Sore throat & $13(14.3)$ \\
\hline Chest pain & $11(12.1)$ \\
\hline Abdominal pain & $11(12.1)$ \\
\hline \multicolumn{2}{|l|}{ Findings of physical examination } \\
\hline \multicolumn{2}{|l|}{ Body temperature $\left({ }^{\circ} \mathrm{C}\right)$} \\
\hline Median (Range) & $38(36.2-40)$ \\
\hline Mean & $37.9 \pm 1.05$ \\
\hline Crackles & $85(93.4)$ \\
\hline Tachypnea & $62(68.1)$ \\
\hline Rhonchi & $54(59.3)$ \\
\hline Cyanosis & $40(44)$ \\
\hline Tachycardia & $39(42.9)$ \\
\hline Nasal flaring & 39 (42.9) \\
\hline Wheezing & $38(41.8)$ \\
\hline Chest retraction & $36(39.6)$ \\
\hline Underweight (<\% 3) & $13(14.3)$ \\
\hline Short stature $(<\% 3)$ & 7 (7.7) \\
\hline
\end{tabular}

$\dagger: \mathrm{n}(\%)$, Data are shown as mean \pm standard deviation, median (range) or percent 
Table 2. The laboratory and microbiological features of the patients with CAP

\begin{tabular}{lc}
\hline Leukocyte count $\left(/ \mathrm{mm}^{3}\right)$ & \\
Median (Range) & $9000(2100-37600)$ \\
CRP (mg/L) & \\
Median (Range) & $10.7(1.3-106.7)$ \\
Procalcitonin (ng/ml) & \\
$\quad$ Median (Range) & $0.13(0.02-75.3)$ \\
ESR (mm/h) & $13(2-80)$ \\
$\quad$ Median (Range) & - \\
RSV & - \\
PIV 1 & $7(7.7) \dagger$ \\
PIV 2 & $2(2.2) \dagger$ \\
PIV 3 & $1(1.1) \dagger$ \\
Adenovirus & - \\
hMPV & \\
Viral coinfection & $2(2.2) \dagger$ \\
PIV3+adenovirus & $1(1.1) \dagger$ \\
PIV2+PIV3 & $11(12.1) \dagger$ \\
Positive blood culture & $1(1.1) \dagger$ \\
Staphylococcus hominis & $5(5.4) \dagger$ \\
Staphylococcus epidermidis & $2(2.2) \dagger$ \\
Staphylococcus saprophyticus & $1(1.1) \dagger$ \\
Staphylococcus capitis & $1(1.1) \dagger$ \\
Streptococcus sobrinus & \\
Streptococcus mitis & \\
\hline & \\
\hline & \\
\hline & \\
\hline
\end{tabular}

$\dagger: \mathrm{n}(\%)$, Data are shown as median (range) or percent

Table 3. The distributions of etiologic agents of community-acquired pneumonia according to age groups

\begin{tabular}{lccccc}
\hline $\begin{array}{l}\text { Age } \\
\text { (Month) }\end{array}$ & \multicolumn{4}{c}{ Number of patients $(\%)$} & \multirow{2}{*}{ Total } \\
\cline { 1 - 4 } Etiology & & Virus & $\begin{array}{c}\text { Positive } \\
\text { blood } \\
\text { culture }\end{array}$ & $\begin{array}{c}\text { Unknown } \\
\text { etiologic } \\
\text { agent }\end{array}$ & \\
\hline$<2$ & $2(12.5)$ & $4(25.1)$ & $10(62.5)$ & $16(17.6)$ \\
\hline $2-11$ & $6(19.4)$ & $4(12.9)$ & $21(67.7)$ & $31(34.1)$ \\
$12-23$ & $1(6.7)$ & $1(6.7)$ & $13(86.7)$ & $15(16.5)$ \\
$24-59$ & $0(0)$ & $2(12.5)$ & $14(87.5)$ & $16(17.6)$ \\
$>59$ & $2(15.4)$ & $0(0)$ & $11(84.6)$ & $13(14.3)$ \\
\hline Total & $11(12.1)$ & $11(12.4)$ & $69(75.8)$ & $91(100)$ \\
\hline
\end{tabular}

infiltration in 24 (26.3\%) of the 91 patients and interstitial infiltration in 35 (38.4\%). There was no statistically significant difference between viral and bacterial pneumonia groups with regard to length of hospitalization $(p=0.252)$. None of the children required mechanical ventilation or died.

\section{DISCUSSION}

Table 4. Chest $x$-ray findings of the patients with CAP

\begin{tabular}{lc}
\hline Radiological findings & $\mathbf{n}(\%)$ \\
\hline Normal & $28(30.8)$ \\
Intercystitial infiltration & $23(25.3)$ \\
Consolidation & $19(20.9)$ \\
Peribronchitis & $12(13.2)$ \\
Air bronchogram & $5(5.5)$ \\
Pleural effusion & $2(2.2)$ \\
Hiler/ mediastinal lymphadenopathy & $1(1.1)$ \\
Atelectasis & $1(1.1)$ \\
Hyperinflation & - \\
\hline
\end{tabular}

The present study showed causative infective agents and characteristics of hospitalized children with pneumonia. Real time-PCR as molecular diagnostic technique was used in our study to comprehensively study the viral etiology of CAP in hospitalized children who were 1 month to 16 years old. Using this method, infection with 6 viruses was investigated, and the presence of viral infection was identified in $12.1 \%$ of the patients. Bacterial infection was detected in 9 (9.9\%) of 91 patients. These results were less than previously reported etiological rates; in previous studies, the rate has been reported as $43 \%$ to $85 \%(6,12,13)$. Epidemiologic data related to pneumococcal diseases are very limited in Turkey, despite the fact that pneumococcus is the most important organism causing childhood bacterial diseases. The emergence and spread of resistant 
pneumococcal strains have led to an emphasis on the prevention of pneumococcal disease by vaccination. Routine vaccination with 7-valent pneumococcal conjugated vaccine (PCV-7) for children $<1$ year of age was agreed upon in Turkey at the end of 2008 and was included in the National Immunization Schedule in 2009. PCV-7 was used for 2 years in Turkey before being replaced by PCV-13 in November 2011. In 2010 and $2011,96 \%$ and $97 \%$ of the target population, respectively, were vaccinated with PCV-7 (14). In our study, Streptococcus pneumoniae was not detected in any of the blood cultures. It can depend on the Vaccine Schedule.

In clinical practice, it is important to distinguish between contamination and bloodstream infections to prevent unnecessary prescription of antimicrobial agents leading to a selection of antimicrobialresistant organisms $(15,16)$. Contamination is usually presumed if only one of at least two sets of blood cultures is positive for Coagulase-negative staphylococci, whereas true bloodstream infection is assumed if at least two blood cultures yield Coagulasenegative staphylococci $(17,18)$. Thus, we made the discrimination of yielding and contamination according to these data.

Iwane et al (19) showed that younger age (particularly $<1$ year), male gender, and presence of chronic underlying illness were associated with higher hospitalization rates for viral acute respiratory illness. In our study, the ratio of male to female was closed to 1 and $51.7 \%$ of patients were younger than 1 year of age. Our results were in accordance with previous studies' findings (20).

In a previous study by Juven et al (21), the most common symptoms were fever in $96 \%$, cough in $76 \%$, rhinorrhea in $48 \%$ and dyspnea in $37 \%$ of the patients with pneumonia. In this study, twenty-four percent of the patients had typical pneumonic rales/ crackles on auscultation. Decreased breathing sounds were found in $15 \%$ of patients, wheezing in $20 \%$ and rhonchi in $33 \%$ of the patients. Auscultation was normal in $28 \%$ of the patients. In our study, the most common symptoms were fever in $98.9 \%$ and cough in $98.9 \%$ of the patients. Auscultation findings of the patients, crackles, rhonchi and wheezing were found in $85(93.4 \%), 54(59.3 \%)$ and $38(41.8 \%)$ children, respectively.

Viruses have been most commonly associated with CAP diagnosed in infants and younger children (22). However, recent evidence suggests that, when sensitive detection methods are used, the prevalence of viral infections in older children with CAP is higher than previously thought (6). In our study, $12.1 \%$ of the patients were found to be infected with viruses. Cilla et al. had investigated 14 respiratory viruses in children aged less than 3 years old with CAP using molecular or immünochromatographic techniques and/or viral culture. In their study, at least one virus had been detected in $66.9 \%$ of the episodes (23).

Juvén et al. (6) reported a very high rate (62\%) of viral etiology in pediatric CAP. In their study, rhinovirus, detected by PCR, accounted for a large proportion of viral pneumonia. In our study, rhinovirus was not investigated.

RSV is accounted for an estimated 13, 3, and 0.4 RSV-associated hospitalizations per 1000 children who were younger than 1 year, 1 year of age, and in children 2 to 5 years of age, respectively (23). In our study, RSV was not detected. The cause for this is clearly unknown.

A recent study showed that the positive detection rate of adenovirus by RT-PCR was $0.63 \%$ in children with pneumonia (24). Similarly, in our study, adenovirus was detected only in one patient in 2-11 months of age group. However, this ratio is lower than in that reported in a study by Samransamruajkit et al. (25) in which adenovirus was detected in $6.6 \%$ of pneumonia patients.

Predictable parainfluenza-related hospitalization rates in the New Vaccine Surveillance Network study were $3.2,1.5$, and 0.4 per 1000 children younger than 1 year, 1 year, and 2 to $<5$ years of age, respectively (19). In our study, PIV-2 had the highest rate among 
detected viruses in all age groups. Parainfluenza 3 were found in $<2$ and 2-11 months of age group. PIV-2 was the most common viral agent among $<2$ and 2-11 months of age group.

Human metapneumovirus, a respiratory virus first isolated in the Netherlands in 2001, has been increasingly recognized as a common cause of acute respiratory tract infection in young children worldwide. Human metapneumovirus infection has been associated with a spectrum of clinical manifestations, ranging from influenza-like illness to bronchiolitis and pneumonia. Among children hospitalized for acute LRI in southern Israel during a 1-year period, human metapneumovirus was detected in $13 \%$ of the patients and was the third most common viral pathogen (26). In our study, human metapneumovirus was not detected.

In a previous study, in $27 \%$ of the episodes of childhood CAP multiple viral infections were detected. Infection severity was more in multiple viral infections than single viral infection due to the greater frequency of hospitalization (23). We also detected viral co-infection in 3 patients. In our study population, mixed infections were uncommon (3.1\%), although in previous studies mixed infections were reported as high as $23 \%$ of pneumonia cases in children (27).

The usefulness of PCT for distinguishing between bacterial and viral pneumonia has been analyzed in children but the data are also conflicting. Moulin et al. found that a PCT value of $1 \mathrm{ng} / \mathrm{ml}$ or greater had better specificity and sensitivity and higher positive and negative predictive values than CRP, IL-6 or white blood cell count for discriminating between bacterial and viral CAP in untreated children admitted to hospital (28). In a similar study Toikka et al. also reported high values of PCT in children with bacterial pneumonia, but with a large overlap between bacterial and viral pneumonia (29). In their study, Don et al. (30) concluded that the four nonspecific inflammatory markers, CRP, PCT, ESR, WBC count and their combinations have a limited role in the separation of bacterial from viral pneumonia in children. In particular, low levels considered as typical for viral infections were not able to rule out bacterial infection. In our study, we also found no statistically significant difference between viral and bacterial pneumonia groups with regard to ESR and PCT values.

In clinical practice, alveolar infiltrations on chest radiograph are often considered to indicate bacterial etiology of pneumonia, but clinical studies have failed to confirm this concept $(31,32)$. Virkki et al.(33) recently found that most children with alveolar infiltrates and, in particular, with lobar infiltrates, had bacterial pneumonia, whereas interstitial infiltrates were present in both viral and bacterial cases. In our study, there were alveolar infiltration in $24(26.3 \%)$ and interstitial infiltration in 35 (38.4\%) of the 91 patients.

This study, like others that investigated viral and bacterial pneumonia, has three major limitations: First of all, documentation of infection in the upper respiratory tract does not necessarily prove the etiological agent of pneumonia. However, in 69 of 91 cases no etiological agent was detected. The RT-PCR method is an extremely powerful and useful tool; however, if we had been included other viral agents including rhinovirus and human bocavirus detected by RT-PCR, numbers of diagnosed cases might be higher. We also did not investigate Mycoplasma pneumoniae serologically. Second, month-to-month variations in the prevalence of different pathogens may affect their association with CAP. Third, the other important limitation is that we only studied hospitalised patients, and the results cannot be generalised to outpatients with pneumonia.

In conclusion, our study demonstrated the etiological influence of viral agents in CAP. Parainfluenza virus 2 was the most common viral agent among detected viruses in all age groups. Improving the etiological diagnosis of viral infections 
may avoid unnecessary antibiotics and allow for preventive isolation of infected patients. Further larger and randomized controlled studies are needed to confirm our results.

\section{CONFLICTS of INTEREST}

The authors declare no conflicts of interest.

\section{REFERENCES}

1. Chiang WC, Teoh $\mathrm{OH}$, Chong CY, Goh A, Tang JP, Chay OM. Epidemiology, clinical characteristics and antimicrobial resistance patterns of communityacquired pneumonia in 1702 hospitalized children in Singapore. Respirology, 2007; 12: 254-61.

2. Mulholland K. Global burden of acute respiratory infections in children:implications for interventions. Pediatr Pulmonol, 2003; 36: 469-74.

3. Paisley JW, Lauer BA, McIntosh K, Glode MP, Schachter J, Rumack C. Pathogens associated with acute lower respiratory tract infection in young children. Pediatr Infect Dis, 1984; 3: 14-9.

4. Nohynek H, Eskola J, Laine E, Halonen P, Ruutu $P$, Saikku P, et al. The causes of hospital-treated acute lower respiratory tract infection in children. Am J Dis Child, 1991; 145: 618-22.

5. Gendrel D, Raymond J, Moulin F, Iniguez JL, Ravilly $\mathrm{S}$, Habib F, et al. Etiology and response to antibiotic therapy of communityacquired pneumonia in French children. Eur J Clin Microbiol Infect Dis, 1997; 16: 388-91.

6. Juvén T, Mertsola J, Waris M, Leinonen M, Meurman $O$, Roivainen $M$, et al. Etiology of communityacquired pneumonia in 254 hospitalized children. Pediatr Infect Dis J, 2000; 19: 293-8.

7. Sinaniotis CA, Sinaniotis AC. Community-acquired pneumonia in children. Curr Opin Pulm Med, 2005; 11: $218-25$.

8. Coiras MT, Pérez-Breña P, García ML, Casas I. Simultaneous detection of influenza A, B, and $C$ viruses, respiratory syncytial virus, and adenoviruses in clinical samples by multiplex reverse transcription nested-PCR assay. J Med Virol, 2003; 69: 132-44.
9. Templeton KE, Scheltinga SA, Beersma MF, Kroes AC, Claas EC. Rapid and sensitive method using multiplex real-time PCR for diagnosis of infections by influenza A and influenza B viruses, respiratory syncytial virus, and parainfluenza viruses $1,2,3$, and 4. J Clin Microbiol, 2004; 42: 1564-9.

10. McIntosh K. Community-acquired pneumonia in children. N Engl J Med, 2002; 346: 429-37.

11. World Health Organization. Technical bases for the WHO recommendation on the management of pneumonia in children at first level health facilities. World Health Organization, 1991, Geneva.

12. Heiskanen-Kosma T, Korppi M, Jokinen C, Kurki S, Heiskanen L, Juvonen $\mathrm{H}$, et al. Etiology of childhood pneumonia: serologic results of a prospective, population-based study. Pediatr Infect Dis J, 1998; 17: 986-91.

13. Wubbel L, Muniz L, Ahmed A, Trujillo M, Carubelli C, McCoig C, et al. Etiology and treatment of community- acquired pneumonia in ambulatory children. Pediatr Infect Dis J, 1999; 18: 98-104.

14. Ceyhan M, Ozsurekci Y, Gürler N, Ozkan S, Sensoy $\mathrm{G}$, Belet $\mathrm{N}$, et al. Distribution of Streptococcus pneumoniae serotypes that cause parapneumonic empyema in Turkey. Clin Vaccine Immunol, 2013; 20: 972-6.

15. Herwaldt LA, Geiss M, Kao C, Pfaller MA. The positive predictive value of isolating coagulasenegative staphylococci from blood cultures. Clin Infect Dis, 1996; 22: 14-20.

16. Rogers KL, Fey PD, Rupp ME. Coagulase-negative staphylococcal infections. Infect Dis Clin North Am, 2009; 23: 73-98. 
17. Seybold U, Reichardt C, Halvosa JS, Blumberg HM. Clonal diversity in episodes with multiple coagulase-negative staphylococcus bloodstream isolates suggesting frequent contamination. Infection, 2009; 37: 256-60.

18. Toldos CM, Yague G, Ortiz G, Segovia M. Assessment of multiple coagulase-negative staphylococci isolated in blood cultures using pulsed-field gel electrophoresis. Eur J Clin Microbiol Infect Dis, 1997; 16: 581-6.

19. Iwane MK, Edwards KM, Szilagyi PG, Walker FJ, Griffin MR, Weinberg GA, et al; New Vaccine Surveillance Network. Population-based surveillance for hospitalizations associated with respiratory syncytial virus, influenza virus, and parainfluenza viruses among young children. Pediatrics, 2004; 113: 1758-64

20. Nascimento-Carvalho $\mathrm{CM}$, Rocha $\mathrm{H}$, Benguigui $\mathrm{Y}$. Effects of socioeconomic status on presentation with acute lower respiratory tract disease in children in Salvador, Northeast Brazil. Pediatr Pulmonol, 2002; 33: 244-8.

21. Juvén T, Ruuskanen O, Mertsola J. Symptoms and signs of community-acquired pneumonia in children. Scand J Prim Health Care, 2003; 21: 52-6.

22. British Thoracic Society. Guidelines for the management of community-acquired pneumonia in childhood. Thorax, 2002; 57: 1-24.

23. Cilla G, Oñate E, Perez-Yarza EG, Montes $M$, Vicente D, Perez-Trallero E. Viruses in communityacquired pneumonia in children aged less than 3 years old: High rate of viral coinfection. J Med Virol, 2008; 80: 1843-9.

24. Lu MP, Ma LY, Zheng Q, Dong LL, Chen ZM. Clinical characteristics of adenovirus associated lower respiratory tract infection in children. World $\mathrm{J}$ Pediatr, 2013; 9: 346-9.
25. Samransamruajkit R, Hiranrat T, Chieochansin T, Sritippayawan S, Deerojanawong J, Prapphal $\mathrm{N}$, et al. Prevalence, clinical presentations and complications among hospitalized children with influenza pneumonia. Jpn J Infect Dis, 2008; 61: 446-9.

26. Wolf DG, Greenberg D, Kalkstein D, Shemer-Avni Y, Givon-Lavi N, Saleh N, et al. Comparison of human metapneumovirus, respiratory syncytial virus and influenza A virus lower respiratory tract infections in hospitalized young children. Pediatr Infect Dis J, 2006; 25: 320-4.

27. Michelow IC, Olsen K, Lozano J, Rollins N Epidemiology and characteristics of community acquired pneumonia in hospitalized children. Pediatrics, 2004; 113: 701-7.

28. Moulin F, Raymond J, Lorrot M, Marc E, Coste J, Iniguez JL, et al. Procalcitonin in children admitted to hospital with community acquired pneumonia. Arch Dis Child, 2001; 84: 332-6.

29. Toikka P, Irjala K, Juven T, Virkki R, Mertsola J, Leinonen $M$, et al (2000) Serum procalcitonin, C-reactive protein and interleukin-6 for distinguishing bacterial and viral pneumonia in children. Pediatr Infect Dis J, 19: 598-602.

30. Don $M$, Valent $F$, Korppi $M$, Canciani $M$. Differentiation of bacterial and viral communityacquired pneumonia in children. Pediatr Int, 2009; 51: 91-6.

31. Isaacs D. Problems in determining the etiology of community acquired childhood pneumonia. Pediatr Infect Dis J, 1989; 8: 143-8.

32. Korppi M , Kiekara O , Heiskanen-Kosma $\mathrm{T}$, Soimakallio $S$. Comparison of radiological findings and microbial aetiology of childhood pneumonia . Acta Paediatr, 1993 ; 82: 360-3.

33. Virkki R, Juven T, Rikalainene $H$, Svedström E, Mertsola J, Ruuskanen O. Differentiation of bacterial and viral pneumonia in children . Thorax, 2002; 57: 438-41. 